\title{
Nonsteroidal anti-inflammatory drugs and prostate cancer: a systematic review of the literature and meta-analysis
}

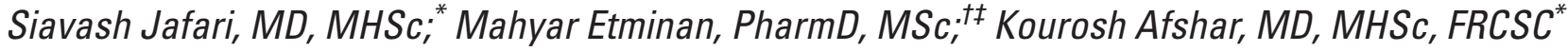

\begin{abstract}
Prostate cancer is the most common visceral cancer in men. Many studies have shown that nonsteroidal anti-inflammatory drugs (NSAIDs) may reduce the risk of prostate cancer. We systematically searched all relevant databases (MEDLINE, EMBASE, The Cochrane Collaboration, CINAHL, Database of Abstracts of Review of Effects and ACP Journal Club) to March 2008. We also explored bibliographies of the articles, pertinent journals and conferences. We selected relevant articles according to predefined inclusion criteria by 2 independent reviewers. We used both fixed and randomeffect models for meta-analysis. We performed subgroup and sensitivity analysis based on predefined variables. From 962 extracted articles, 20 met the inclusion criteria with a total of 25768 participants. All the studies had an observational design. There was a statistically significant protective effect for NSAIDs on risk of prostate cancer (odds ratio [OR] 0.92, 95\% confidence interval [Cl] 0.86-0.97). Subgroup analysis did not show any effect of study design or quality score on the results. There was a small but statistically significant protective effect for acetylsalicylic acid (ASA) (OR 0.95, 95\% Cl 0.91-1.00). Exposure to non-ASA NSAIDs was associated with a slightly reduced likelihood of prostate cancer (OR 0.92, 95\% Cl 0.85-1.00). With the available data, we were not able to determine an optimum dosage for NSAIDs. We conclude that taking NSAIDs may reduce the risk of prostate cancer. Nevertheless, the effect is small.
\end{abstract}

Can Urol Assoc J 2009;3(4):323-30

\section{Résumé}

Le cancer de la prostate est le cancer viscéral le plus fréquent chez I'homme. Bon nombre d'études ont montré que les antiinflammatoires non stéroïdiens (AINS) pouvaient réduire le risque de cancer de la prostate. Notre objectif était de réaliser une revue systématique et une méta-analyse des articles publiés sur les effets des AINS dans la réduction du risque de cancer de la prostate. Toutes les bases de données pertinentes (MEDLINE, EMBASE, Collaboration Cochrane, CINAHL, Database of Abstracts of Review of Effects et ACP Journal Club) ont été systématiquement consultées en mars 2008. On a également examiné la bibliographie des articles dégagés et des revues et conférences pertinentes. Les articles pertinents ont été sélectionnés en fonction de critères d'inclusion prédéfinis par 2 analystes indépendants. Pour la méta-analyse, on a eu recours à des modèles à effets fixes et à effets aléatoires. Une analyse par sous-groupes et une analyse de sensibilité ont été effectuées à l'aide de variables prédéfinies. Sur les 962 articles dégagés, 20 satisfaisaient aux critères d'inclusion, pour un total de 25768 sujets. Toutes les études étaient de type observationnel. On a noté un effet protecteur statistiquement significatif sur le risque de cancer de la prostate avec les AINS (rapport de cotes de 0,92 ; IC à $95 \%$ de 0,86 à 0,97 ). L'analyse par sous-groupes n'a révélé aucun effet du plan de l'étude ou du score de qualité sur les résultats. On a noté un effet protecteur léger mais tout de même significatif sur le plan statistique avec l'aspirine (RC 0,95; IC à $95 \%$ de 0,91 à 1,00). L'exposition à des AINS autres que l'aspirine a été associée à une probabilité légèrement moindre de cancer de la prostate (RC 0,92, IC à $95 \%$ de 0,85 à 1,00). Les données disponibles ne nous ont pas permis de déterminer la posologie optimale des AINS. Nous avons observé un effet favorable possible associé à la prise d'AINS dans la réduction du risque de cancer de la prostate, mais cet effet est minime.

\section{Introduction}

Prostate cancer is the most common malignancy among men in Western countries. Older age, African American race and family history are the 3 well-established and nonmodifiable risk factors for prostate cancer. Modifiable lifestyle factors that may affect the risk of prostate cancer include diet, smoking habits, exercise and body size. ${ }^{1}$ The development of prostate cancer involves many cellular pathways, which could be targeted for prevention or treatment. For example, chemoprevention using antiandrogens has been shown to reduce the risk of prostate cancer by $25 \%{ }^{2}$ There is evidence that inflammatory pathways may be involved in the development of prostate cancer. ${ }^{3-6}$ This has lead to the hypothesis that acetylsalicylic acid (ASA) and other nonsteroidal anti-inflammatory drugs (NSAIDs) may reduce the risk of prostate cancer.

The primary objective of this meta-analysis was to assess the effect of NSAIDs on the incidence of prostate cancer, using a systematic review of all available studies and metaanalytic techniques when appropriate. The primary study question in this review is, Do NSAIDs reduce the risk of 
prostate cancer? Secondary questions include the following: In the case that a protective effect is observed, does this benefit differ among NSAID and ASA users? Is the effect dose-dependent?

\section{Methods}

We searched all relevant databases to March 2008 and identified one systematic review. ${ }^{7}$ However, since the publication of this review, other observational studies have been published that warrant a more up-to-date systematic review.

\section{Search protocol}

We identified relevant studies and abstracts by searching MEDLINE (1966 to March 2008); CINHAL (1982 to March 2008), ACP Journal Club (1991 to March 2008), Database of Abstracts of Reviews of Effects (1990 to March 2008), and The Cochrane Collaboration Controlled Trials Register for studies published before March 2008. The following search terms were used: "prostate," "prostate cancer," "prostate neoplasm," "prostate carcinoma," "aspirin," "antiinflammatory drugs," "NSAIDs," "NSAID," "Cyclooxygenase II inhibitors," "Cox-2 inhibitor," "Celecoxib," "ibuprofen," "naproxen," "diclofenac sodium," "mefenamic acid," "indometacine" and "piroxicam."

We combined the sensitive strategies of the Cochrane handbook for systematic reviews of interventions ${ }^{8}$ to search relevant studies in MEDLINE and EMBASE. Retrieved studies were assessed for any text words or medical subject headings for NSAIDs therapy that have not been used. We also incorporated any new terms that were identified into the search strategy.

In addition, we screened the bibliographies of identified publications for further citations. We also hand searched the reference lists of retrieved studies, journals related to prostate, cancer, epidemiology, and abstracts and books of cancer and urology conferences.

\section{Study inclusion}

Figure 1 illustrates the process we used for inclusion and exclusion of literature. Studies were eligible if they were randomized controlled trials, case-control, nested case-control, cohort or cross-sectional studies. We included studies if they met the following criteria: 1) exposure to NSAIDs (defined as any nonsteroidal medication that can reduce production of prostaglandins and thromboxane) was explicitly stated, 2) relative risks (RRs) or odds ratios (ORs) were provided or could be estimated form provided data, and 3) diagnosis of prostate cancer was made based on histological diagnosis or through an established tumour registry database.
We used a standard data extraction form to record the extracted information. We included all studies evaluating the effects of NSAIDs and/or ASA, with any duration or dosage. After the elimination of irrelevant articles (e.g., basic science, animals studies or case reports), 2 authors (S.J. and K.A.) independently reviewed the extracted papers. Discrepancies were settled by discussion among all authors.

\section{Methodological quality of included studies}

Two reviewers (S.J. and K.A.) independently assessed the study quality according to modified criteria previously used by Lichtenstein and colleagues. ${ }^{9}$ These criteria include an explicit statement of the research question, a description of cases and controls selection, definition of ASA or NSAID exposure, information on data collection, analytic methods and sample size. We generated an overall quality score (0 to 10) and ranked the studies. Two independent reviewers scored the study quality in a blinded manner to ensure unbiased review.

\section{Data abstraction}

We abstracted data onto structured forms designed to capture relevant information in a concise, focused fashion. Age was recorded as the range, mean, standard deviation and/or median (whichever available). Study name, population of study, year of study and publication, study design, sample size, type of drug, duration and dosage of use, adjustments, and method of diagnosis of prostate cancer were recorded.

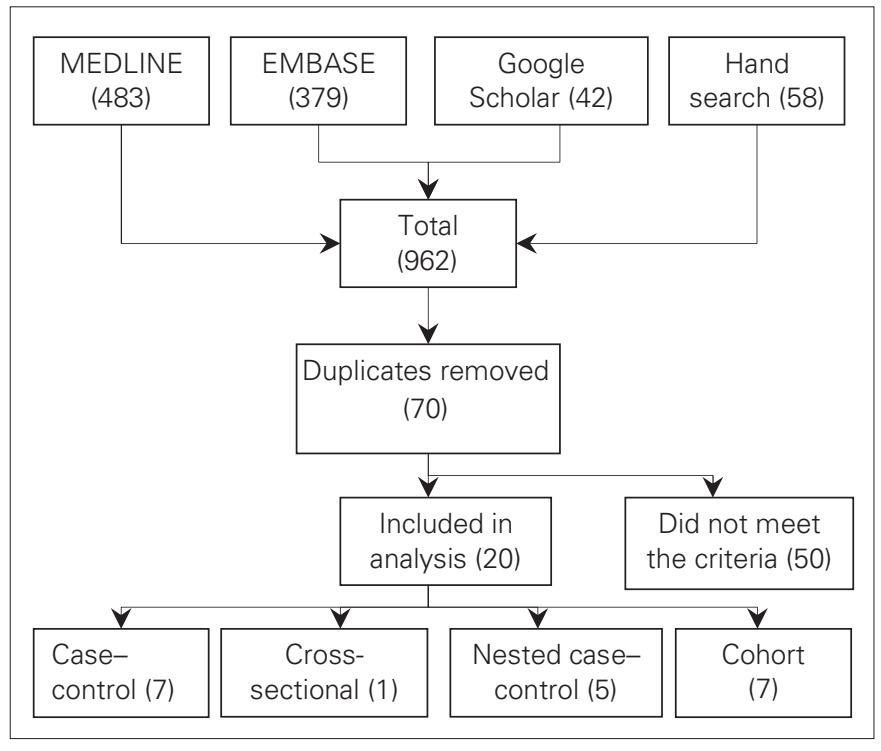

Fig. 1. Literature inclusion and exclusion process. 


\section{Analysis}

We extracted the number of prostate cancer events in NSAID/ASA users and controls, and calculated the pooled fixed and random effect estimates of the odds ratio for risk of prostate cancer. We performed Cochran Q test and estimated $R$ index to test for heterogeneity across studies. We did subgroup analyses based on several predefined variables such as study type and drugs categories (ASA v. NSAIDs). We conducted Duval \& Tweedie' ${ }^{10}$ trim and fill method to test for possibility of publication bias.

\section{Results}

\section{Characteristics of included studies}

No randomized controlled trial was identified. Twenty observational studies with a total of 25768 participants were included. ${ }^{11-30}$ Characteristics of these studies are presented in Table 1 . One study was published in a conference proceeding in 2002, and published again with a smaller sample size in 2005. ${ }^{21}$ We included the more recent study. Study populations varied in their age and in the stage of

Table 1. Characteristics of studies included in the meta-analysis

\begin{tabular}{|c|c|c|c|c|c|c|c|c|c|c|}
\hline Study; year & Site & Design & $\begin{array}{l}\text { Total } \\
\text { cases }\end{array}$ & $\begin{array}{l}\text { Mean/ } \\
\text { range of } \\
\text { age, yr }\end{array}$ & $\begin{array}{l}\text { Outcome } \\
\text { of interest }\end{array}$ & OR & $95 \% \mathrm{Cl}$ & $\begin{array}{l}\text { Drug } \\
\text { type }\end{array}$ & $\begin{array}{l}\text { Study } \\
\text { period }\end{array}$ & $\begin{array}{c}\text { Source of } \\
\text { data }\end{array}$ \\
\hline $\begin{array}{l}\text { Norrish et al. }{ }^{24} \text {; } \\
1998\end{array}$ & Europe & $\mathrm{CC}$ & 317 & 70 & PC & 0.88 & $0.64-1.20$ & $N \& A$ & 1996 & Questionnaire \\
\hline $\begin{array}{l}\text { Neugut, et al. }{ }^{23} \text {; } \\
1998\end{array}$ & USA & $\mathrm{CC}$ & 319 & 69 & PC & 1.60 & $0.82-3.11$ & ASA & 1984-1986 & Records \\
\hline $\begin{array}{l}\text { Nelson and } \\
\text { Harris }^{22} ; 2000\end{array}$ & USA & $\mathrm{CC}$ & 417 & 64 & PC & 0.34 & $0.23-0.58$ & $N \& A$ & 1992-1995 & Interview \\
\hline Irani et al. ${ }^{15}, 2002$ & France & $\mathrm{CC}$ & 639 & 66.8 & PC & 0.80 & $0.64-0.99$ & $N \& A$ & 1999-2000 & Interview \\
\hline $\begin{array}{l}\text { Menezes et al. }{ }^{21} \\
2005\end{array}$ & USA & $\mathrm{CC}$ & 1029 & 67.1 & PC & 1.05 & $0.89-1.25$ & ASA & 1982-1998 & Questionnaire \\
\hline $\begin{array}{l}\text { Bosetti et al. }{ }^{11} ; \\
2006\end{array}$ & Europe & $\mathrm{CC}$ & 1261 & $46-74$ & PC & 1.10 & $0.81-1.50$ & ASA & $1991-2002$ & Interview \\
\hline Liu et al. ${ }^{19} ; 2006$ & USA & $\mathrm{CC}$ & 506 & - & PC & 0.67 & $0.52-0.87$ & $N \& A$ & 2001-2004 & Interview \\
\hline $\begin{array}{l}\text { Sørensen et al. }{ }^{29} \text {; } \\
2003\end{array}$ & Europe & NCC & 324 & - & PC & 1.30 & $1.20-1.50$ & NSAID & 1989-1995 & Database \\
\hline $\begin{array}{l}\text { Rodríguez and } \\
\text { Gonzalez-Perez } \\
2004\end{array}$ & UK & NCC & 2185 & $50-79$ & PC & 0.93 & $0.71-1.21$ & $N \& A$ & 1995-2001 & Database \\
\hline $\begin{array}{l}\text { Mahmud et al. }{ }^{20} \text {; } \\
2006\end{array}$ & Canada & CS & 1299 & 63 & PC & 0.71 & $0.48-1.03$ & NSAID & 1999-2003 & Interview \\
\hline $\begin{array}{l}\text { Dasgupta et al. }{ }^{12} \text {; } \\
2006\end{array}$ & Canada & NCC & 2025 & 73 & PC & 0.71 & $0.58-0.86$ & $N \& A$ & 1999-2002 & Database \\
\hline $\begin{array}{l}\text { Langman et al. }{ }^{17} \text {; } \\
2000\end{array}$ & UK & NCC & 1813 & - & PC & 1.34 & $1.09-1.64$ & NSAID & 1993-1995 & Database \\
\hline Perron et al. ${ }^{26} ; 2003$ & Canada & NCC & 2221 & 75.7 & PC & 1.14 & $0.83-1.57$ & $N \& A$ & 1993-1996 & Database \\
\hline $\begin{array}{l}\text { Schreinemachers } \\
\text { and Everson }{ }^{28} ; 1994\end{array}$ & USA & Cohort & 123 & 65 & PC & 0.95 & $0.66-1.35$ & ASA & 1971-1987 & Interview \\
\hline $\begin{array}{l}\text { Paganini-Hill et al. }{ }^{25} \text {; } \\
1989\end{array}$ & USA & Cohort & 149 & 73 & PC & 0.90 & $0.63-1.30$ & ASA & $1981-1988$ & Questionnaire \\
\hline Habel et al. ${ }^{14} ; 2002$ & USA & Cohort & 2574 & $18-84$ & PC & 0.76 & $0.60-0.98$ & ASA & 1964-1996 & Questionnaire \\
\hline $\begin{array}{l}\text { Leitzmann et al. }{ }^{18} \text {; } \\
2002\end{array}$ & USA & Cohort & 2479 & $40-75$ & PC & 1.05 & $0.96-1.14$ & ASA & 1986-1996 & Questionnaire \\
\hline $\begin{array}{l}\text { Roberts et al. }{ }^{27} \text {; } \\
2002\end{array}$ & USA & Cohort & 91 & 64 & $\mathrm{PC}$ & 0.45 & $0.28-0.73$ & NSAID & 1990-1996 & Interview \\
\hline $\begin{array}{l}\text { Jacobs et al. }{ }^{16} \\
2005\end{array}$ & USA & Cohort & 4853 & - & $\mathrm{PC}$ & 0.95 & $0.86-1.05$ & $N \& A$ & 1992-1993 & Questionnaire \\
\hline Platz et al. ${ }^{30}$ & USA & Cohort & 1244 & - & $\mathrm{PC}$ & 0.71 & $0.49-1.02$ & $N \& A$ & 1980-2004 & Database \\
\hline
\end{tabular}


their prostate cancer. Sources of data were identified for only 20 studies: 14 from interviews and 6 from databases or medical records. Factors adjusted for varied among the studies and included age, education, ethnic origin, family history of prostate cancer, diet, body mass index, height and weight.

Figure 2 presents the funnel plot of pooled data using the trim and fill method (RevMan-5 Cochrane Collaboration). Although analysis revealed no evidence in favour of publication bias, the funnel plot shows that the majority of

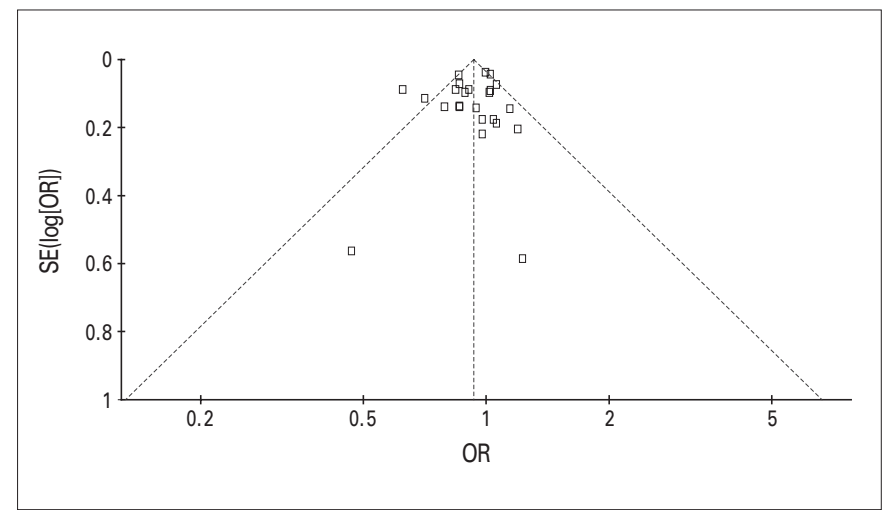

Fig. 2. Funnel plot of pooled data using trim and fill technique. $\mathrm{OR}=$ odds ratio; $\mathrm{SE}=$ standard error studies are grouped in the upper part. This is consistent with lack of small studies favouring positive effect of NSAIDs/ASA in preventing prostate cancer. All results are estimates from random effect model.

Pooled OR for prostate cancer in patients exposed to NSAIDs is $0.92(95 \% \mathrm{Cl} 0.86-0.97)$. The test of heterogeneity was positive $\left(R^{2}=56 \%, d f=23 ; p<0.001\right)$ (Fig. 3).

The type of study did not affect the findings. Studies were divided into 2 main types of case-control and cohort. Analysis of 13 case-control studies revealed a summary 0.91 (95\% Cl 0.84-0.99). The summary OR for 7 cohort studies was 0.94 (95\% Cl 0.86-1.02). Analysis of 15 highquality studies (quality score $\geq 7 / 10$ ) revealed a pooled OR of 0.96 (95\% Cl 0.91-1.01). There was no significant difference in effect size based on the quality scores (Table 2). When we analyzed data from the 13 studies that used questionnaires to capture exposure data compared with studies that used large administrative database, a small protective effect was seen among the questionnaire studies (OR 0.93, $95 \% \mathrm{Cl}$ 0.88-0.98) compared with database studies (OR $1.04,95 \% \mathrm{Cl} 0.93-1.16)$.

We also analyzed studies with separate data for ASA and non-ASA NSAIDs (Fig. 4 and Fig. 5). Sixteen studies reported the effect of ASA exposure. Results of our analysis reveal a pooled OR of 0.95 (95\% Cl 0.91-1.00).

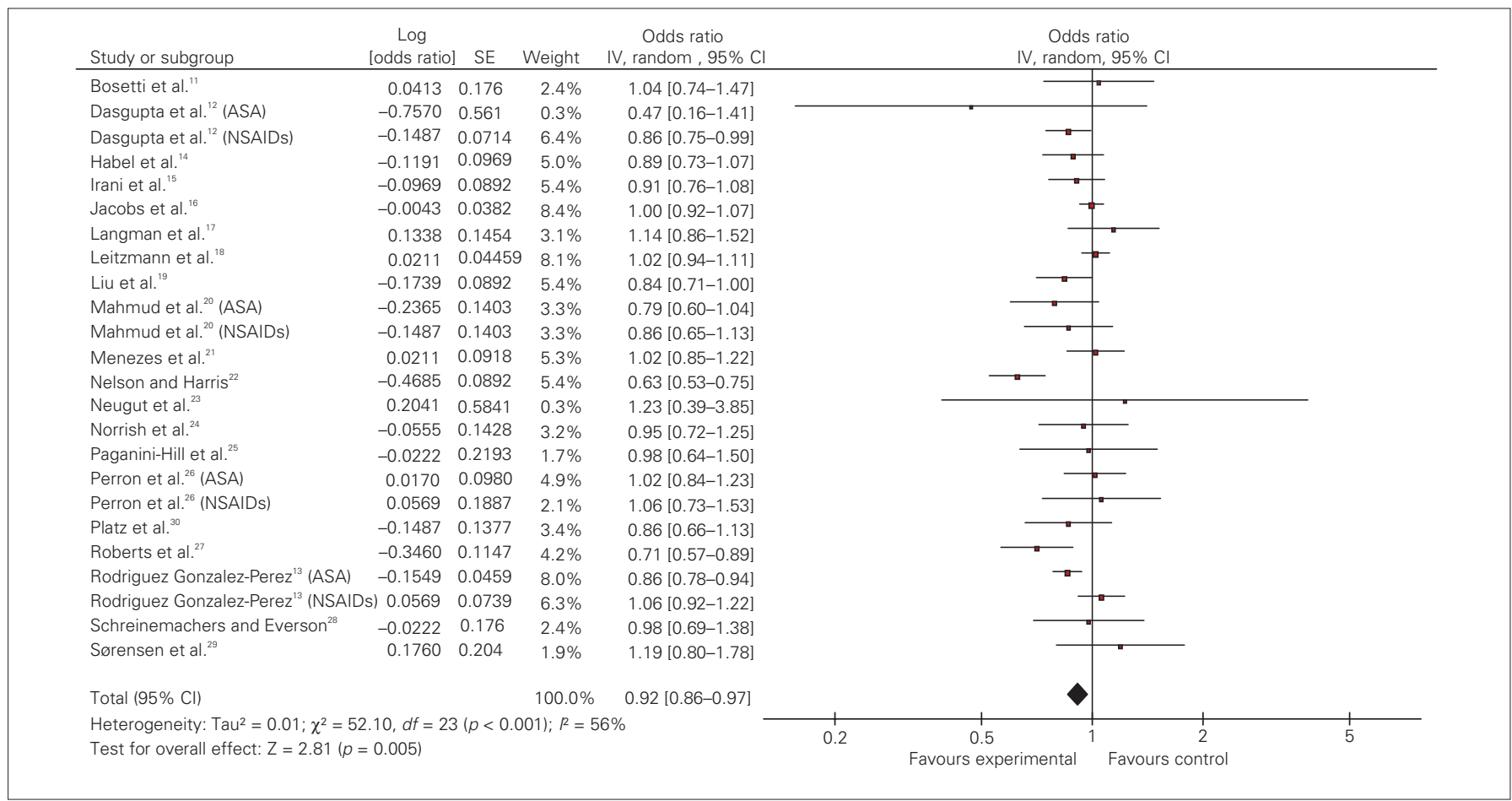

Fig. 3. Effect of nonsteroidal anti-inflammatory drugs (NSAIDs) on prostate cancer risk: random effect model. $\mathrm{ASA}=$ acetylsalicylic acid; $\mathrm{Cl}=\mathrm{confidence}$ interval; IV = intravenous; $\mathrm{SE}=$ standard error. 
Thirteen studies reported the effect of non-ASA NSAIDs with a pooled OR of $0.92(95 \% \mathrm{Cl} 0.85-1.00)$.

\section{Discussion}

The molecular pathogenesis of prostate cancer has been characterized by alterations of genes and proteins involved in proinflammatory pathways. ${ }^{31,32}$ Epidemiological evidence suggests there is a close association between inflammation and prostate cancer. ${ }^{3-6}$ Several studies have demonstrated higher expression of Cyclo-oxygenase 2 (COX-2) in prostate cancer. ${ }^{33-36}$ Studies have revealed the COX-2 dependent and independent mode of action of selective COX-2 inhibitors against prostate cancer..$^{37-39}$ Inflammatory pathway not only may be involved in carcinogenesis, but may also facilitate progression, local invasion, recurrence and metastasis. ${ }^{40,41}$ In a phase II study, Pruthi and colleagues ${ }^{42}$ showed a slowing effect of COX inhibitor celecoxib on the rate of prostatespecific antigen (PSA) rise after biochemical failure of local treatment of prostatic carcinoma. These findings have brought up the possibility of using anti-inflammatory drugs as a means of preventing this disease.

This meta-analysis attempts to evaluate the effectiveness of NSAIDs in reducing the risk of prostate cancer. Based on available studies, use of NSAIDs may have a $5 \%$ to $8 \%$ protective effect against prostate cancer. When ASA and other NSAIDs are analyzed separately, a statistically significant protective effect is still seen. The risk reduction is $5 \%$ for ASA and $8 \%$ for other NSAIDs. Our results are comparable to those of the meta-analysis by Mahmud and coauthors. ${ }^{7}$ Four studies reported OR for ASA and non-ASA NSAID separately. ${ }^{12,13,20,26}$ These studies posed a challenge to calculate the pooled OR, since they used the same sample for 2 different exposures. To remedy this problem we performed 4 different analyses: excluding these studies, including only ASA or only NSAID data, and including both exposures as if they were from 2 independent samples. The results were similar. The pooled OR varied between 0.93 and 0.95 with very close $95 \% \mathrm{Cl}$. We have only presented the latter analysis in Figure 3.

There are several potential pitfalls to this meta-analysis. Like any other systematic review, there may be a publication bias which cannot be entirely ruled out based on funnel plot. There is moderate heterogeneity in the results of the included studies, with the lowest for ASA only studies. This may be due to several factors such as study quality, methodological design, tools used to confirm the exposure or the outcome, variations in defining the exposure and background differences in patient

\begin{tabular}{|c|c|c|c|c|c|c|}
\hline Author & $\begin{array}{l}\text { Study } \\
\text { design }\end{array}$ & $\begin{array}{l}\text { Inclusion/ } \\
\text { exclusion* }\end{array}$ & $\begin{array}{l}\text { Types of } \\
\text { control }\end{array}$ & Adjustment & $\begin{array}{l}\text { Dose/duration } \\
\text { of use }\end{array}$ & $\begin{array}{l}\text { Total } \\
\text { score }\end{array}$ \\
\hline Norrish et al. ${ }^{24}$ & 2 & 1 & 2 & 2 & 1 & 8 \\
\hline Neugut, et al. ${ }^{23}$ & 2 & 1 & 1 & 2 & 0 & 7 \\
\hline Nelson and Harris ${ }^{22}$ & 2 & 1 & 1 & 2 & 2 & 8 \\
\hline Irani et al. ${ }^{15}$ & 2 & 0 & 1 & 2 & 1 & 6 \\
\hline Menezes et al. ${ }^{21}$ & 2 & 1 & 1 & 2 & 1 & 7 \\
\hline Bosetti et al. ${ }^{11}$ & 2 & 1 & 1 & 2 & 1 & 7 \\
\hline Liu et al. ${ }^{19}$ & 2 & 1 & 1 & 2 & 2 & 8 \\
\hline Langman et al. ${ }^{17}$ & 3 & 0 & 2 & 2 & 1 & 8 \\
\hline Perron et al. ${ }^{26}$ & 3 & 1 & 2 & 1 & 2 & 9 \\
\hline Sørensen et al. ${ }^{29}$ & 3 & 0 & 2 & 1 & 0 & 6 \\
\hline $\begin{array}{l}\text { Rodríguez and Gonzalez- } \\
\text { Perez }\end{array}$ & 3 & 1 & 2 & 2 & 2 & 10 \\
\hline Mahmud et al. ${ }^{20}$ & 1 & 1 & 1 & 2 & 1 & 6 \\
\hline Dasgupta et al. ${ }^{12}$ & 3 & 1 & 1 & 2 & 1 & 8 \\
\hline $\begin{array}{l}\text { Schreinemachers and } \\
\text { Everson }^{28}\end{array}$ & 3 & 1 & 2 & 2 & 0 & 8 \\
\hline Paganini-Hill et al. ${ }^{25}$ & 3 & 1 & 1 & 1 & 1 & 7 \\
\hline Habel et al. ${ }^{14}$ & 3 & 1 & 1 & 2 & 2 & 9 \\
\hline Leitzmann et al. $^{18}$ & 3 & 1 & 1 & 2 & 1 & 8 \\
\hline Roberts et al. ${ }^{27}$ & 3 & 1 & 1 & 2 & 1 & 8 \\
\hline Jacobs et al. ${ }^{16}$ & 3 & 1 & 1 & 2 & 1 & 8 \\
\hline Platz et al..$^{30}$ & 3 & 1 & 1 & 2 & 2 & 9 \\
\hline
\end{tabular}


populations. Patients exposed to any of the NSAIDs or ASA may differ in several other aspects that are relevant to the risk of the development of prostate cancer or its detection. For instance, results of a recent study showed that the potential protective effect of NSAIDs on prostate cancer may only exist among certain subgroups of men with particular variants of inflammatory response genes $\angle T A+80 C C .{ }^{19}$

We performed subgroup analysis to further explore the possible factors affecting our analysis based on RRs shown in Figure 3. We evaluated the studies according to their design: case-control versus cohort versus nested casecontrol. The type of study did not affect the findings significantly. We divided the studies into 2 groups according to their quality score: high quality with a score 7 or more out of 10 and lower quality with a score less than 7. Subgroup analysis revealed no difference between the findings in these

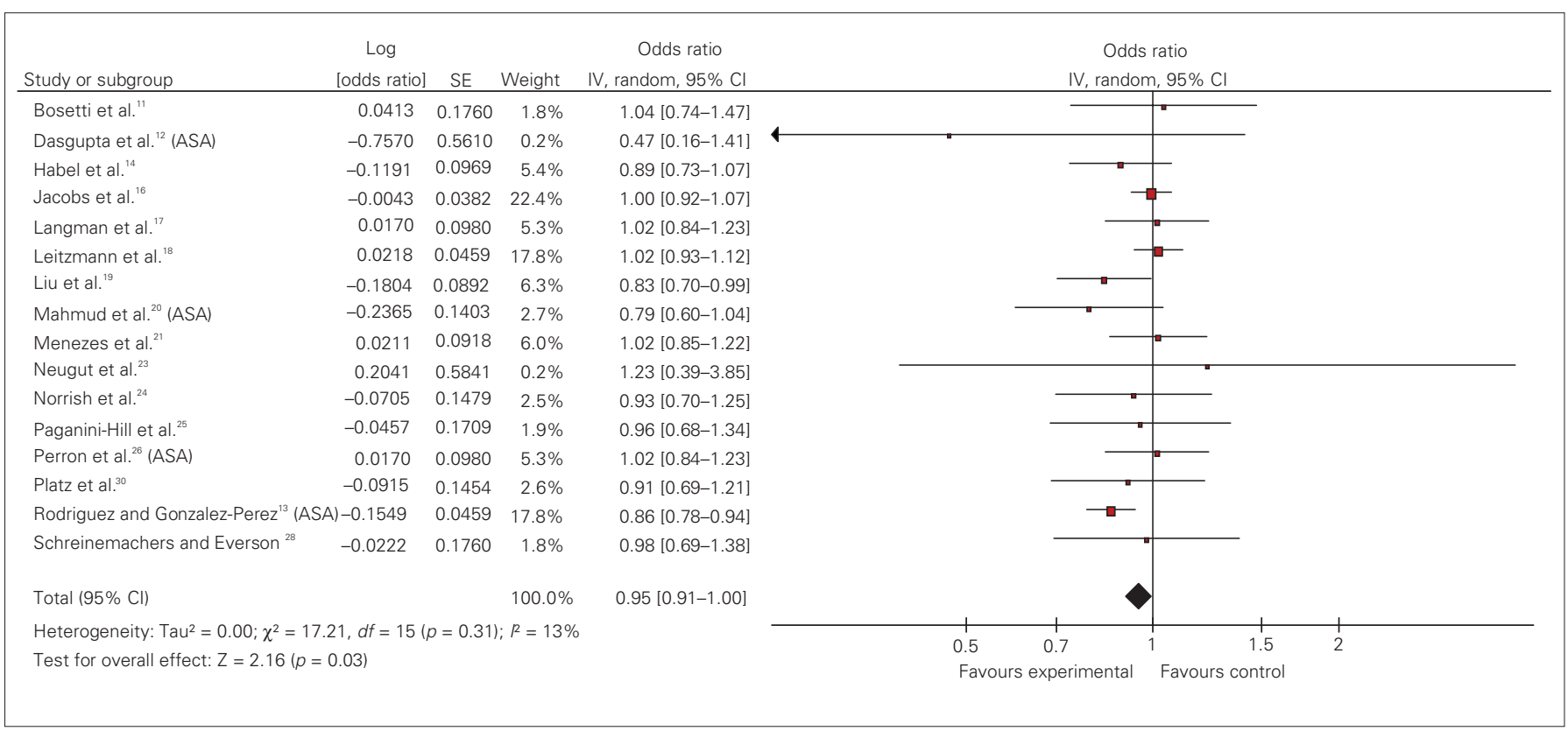

Fig. 4. Effect of acetylsalicylic acid (ASA) on prostate cancer risk: random effect model. $\mathrm{Cl}=$ confidence interval; $I V=$ intravenous; $\mathrm{SE}=$ standard error.

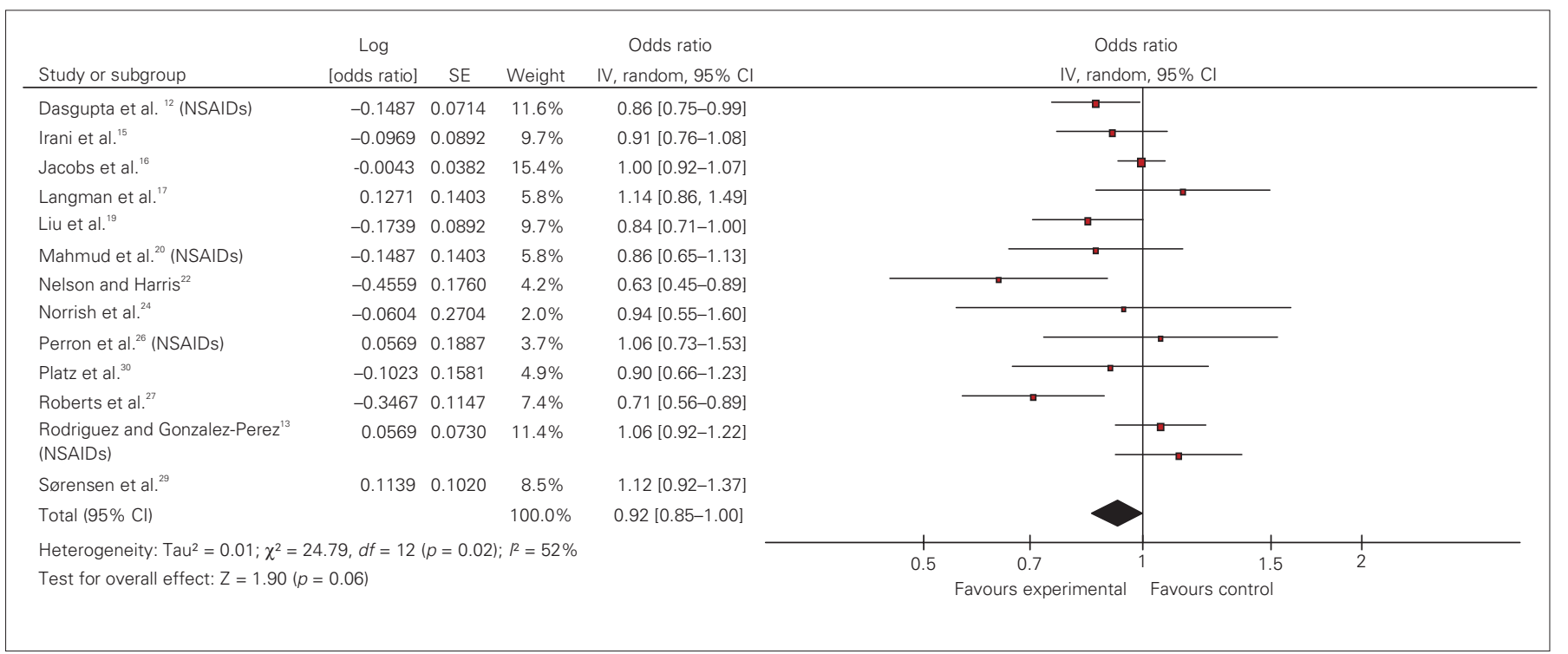

Fig. 5. Effect of non-acetylsalicylic acid nonsteroidal anti-inflammatory drugs (NSAIDs) on prostate cancer risk: random effect model. $\mathrm{Cl}=\mathrm{confidence}$ interval; IV = intravenous; $\mathrm{SE}=$ standard error. 
2 groups (Table 3). We acknowledge that using a scoring system in this situation is controversial. The result of our subgroup analysis may have been affected by the inability of the scoring system to probe into areas specific to studies of prostate cancer.

In most studies use of NSAIDs was categorized as frequent, ever used or never used and the exact nature and duration of drug use is largely unknown. Although NSAIDs inhibit COX enzymes, the degree of this effect is variable among different NSAIDs. Furthermore, concurrent use of NSAIDs and ASA is another possibility, as many of these medications are available over the counter. Also, based on available studies, it was not possible to investigate the potential effect of different dosing regimens. Therefore, a clinically meaningful recommendation about the optimal duration and dose of NSAIDs or ASA use to prevent prostate cancer is evasive.

To confirm the exposure, questionnaires were used in some studies and prescription database in others. Recall bias is a well-known weakness of questionnaires. The extent of recall bias is related to characteristics of the exposure of interest and of the respondents. ${ }^{43,44}$ The level of experience of interviewers, reliability of the tool used to obtain data, and the characteristics of interviewees are among the most important factors that can affect the recall bias. On the other hand, medication database may fail to document over-thecounter use. We performed a subgroup analysis to further explore this issue. Studies using interview and/or questionnaires showed a small protective effect for NSAIDs, which was not seen when a database was used.

Meta-analysis of observational studies may suffer from bias in the original studies. Sources of data for studies included in our analysis were from various countries such as

\begin{tabular}{|c|c|c|c|}
\hline Variable & Total & OR & $95 \% \mathrm{Cl}$ \\
\hline \multicolumn{4}{|l|}{ Drug type } \\
\hline Non-ASA NSAIDS only & 12 & 0.92 & $0.85-1.00$ \\
\hline ASA only & 13 & 0.95 & $0.91-1.00$ \\
\hline \multicolumn{4}{|l|}{ Quality of study } \\
\hline High & 15 & 0.96 & $0.91-1.01$ \\
\hline Low & 4 & 0.92 & $0.76-1.12$ \\
\hline \multicolumn{4}{|l|}{ Source of data } \\
\hline Questionnaire & 13 & 0.93 & $0.88-0.98$ \\
\hline Database & 6 & 1.04 & $0.93-1.16$ \\
\hline \multicolumn{4}{|l|}{ Study design } \\
\hline Case-control & 7 & 0.84 & $0.67-1.07$ \\
\hline Nested case-control & 5 & 1.04 & $0.76-1.41$ \\
\hline Cohort & 6 & 0.89 & $0.77-1.03$ \\
\hline
\end{tabular}

the United States, Canada, New Zealand and France. Background incidence depends on ethnicity and variability of PSA screening programs, which may be different in various countries (screening bias). Confounding by indication may affect the findings. This occurs when the medication used is associated with a condition that may affect the risk of prostate cancer detection. It is possible that users of ASA have a shorter life span than nonusers because of cardiovascular diseases. This may result in a lower chance of being screened and diagnosed with prostate cancer, overestimating the protective effect. ${ }^{45}$ Other types of bias may exist in studies dealing with prostate cancer, such as protopathic bias (when an exposure is influenced by early stages of a disease) and survivor bias (large number of exposed participants who have died from old age). Dissimilarity of study population could be a source of bias in case-control studies. For example, participants selected from referral centres cannot be a true representative of the general population (referral bias). The best way to eliminate bias is a prospective randomized experimental design. But until this type of study is available we are limited to observational studies that should be interpreted with all these limitations in mind.

\section{Conclusion}

Results of this meta-analysis reveal that NSAIDs provide some degree of protective effect against prostate cancer. This effect was seen for both ASA and other NSAIDs. Further experimental studies are required to confirm these findings and determine the optimal dosage and duration of NSAIDs.

From the *Department of Urologic Sciences, University of British Columbia, Vancouver, BC, †Centre for Clinical Epidemiology and Evaluation, Vancouver, BC, and the £Department of Medicine, University of British Columbia, Vancouver, BC

This article has been peer reviewed.

Competing interests: None declared.

\section{References}

1. Chan JM, Gann PH, Giovannucci EL. Role of diet in prostate cancer development and progression. J Clin Oncol 2005;23:8152-60.

2. Thompson $I M$, Goodman PJ, Tangen $C M$, et al. The influence of finasteride on the development of prostate cancer. N Engl J Med 2003;349:215-24.

3. Narayanan BA, Narayanan NK, Pttman B, et al. Adenocarcina of the mouse prostate growth inhibition by Celecoxib: down regulation of transcription factors involved in COX-2 inhibition. Prostate 2006;66:25765.

4. Dennis LK, Dawson DV. Meta-analysis of measures of sexual activity and prostate cancer. Epidemiology 2002;13:72-9.

5. Dennis LK, Lynch CF, Torner JC. Epidemiologic association between prostatitis and prostate cancer. Urology 2002; $60: 78-83$.

6. Roberts OR, Jacobson DJ, Girman CJ, et al. Prostate cancer and non-steroid anti-inflammatory drugs: a protective association. Proceedings of the American Association for Cancer Research Annual Meeting; 
Jafari et al.

2001 Mar. 24-28; New Orleans: MN Merck Research Laboratories. p. 767.

7. Mahmud S, Franco E, Aprikian A. Prostate cancer and use of nonsteroidal anti-inflammatory drugs: systematic review and meta-analysis. Br I Cancer 2004;90:93-9.

8. Higgins JPT, Green S, editors. Cochrane handbook for systematic reviews of interventions 4.2.6. In: The Cochrane Library, Issue 4. Chichester (UK): John Wiley \& Sons, Ltd; 2006.

9. Lichtenstein MJ, Mulrow CD, Elwood PC. Guidelines for reading case-control studies. J Chronic Dis 1987; 40:893-903.

10. Duval SJ, Tweedie RL. A non-parametric "trim and fill" method of accounting for publication bias in metaanalysis. J Am Stat Assoc 2000;95:89.

11. Bosetti C, Talamini R, Negri E, et al. Aspirin and the risk of prostate cancer. Eur J Cancer Prev 2006; 15:43-5.

12. Dasgupta K, Di Cesar D, Ghosn J, et al. Association between nonsteroidal anti-inflammatory drugs and prostate cancer occurrence. Cancer J 2006;12:130-5.

13. Garcia Rodriguez LA, Gonzalez-Perez A. Inverse association between nonsteroidal anti-inflammatory drugs and prostate cancer. Cancer Epidemiol Biomarkers Prev 2004;13:649-53.

14. Habel LA, Zhoo W, Stanford JL. Daily aspirin use and prostate cancer risk in a large, multiracial cohort in the US. Cancer Causes Control 2002;13:427-34.

15. Irani J, Ravery V, Pariente JL, et al. Effect of nonsteroidal anti-inflammatory agents and finasteride on prostate cancer risk. J Urol 2002;168:1985-8.

16. Jacobs EJ, Rodriguez C, Mondul AM, et al. A large cohort study of aspirin and other nonsteroidal antiinflammatory drugs and prostate cancer incidence. J Natl Cancer Inst 2005;97:975-80.

17. Langman MJ, Cheng KK, Gilman EA, et al: Effect of anti-inflammatory drugs on overall risk of common cancer: case-control study in general practice research database. BMJ 2001;320:1642.

18. Leitzmann MF, Stampfer MJ, Ma J, et al. Aspirin use in relation to risk of prostate cancer. Cancer Epidemiol Biomarkers Prev 2002;11:1108-11.

19. Liu X, Plummer SJ, Nock NL, et al. Nonsteroidal anti-inflammatory drugs and decreased risk of advanced prostate cancer: modification by lymphotoxin alpha. Am J Epidemiol 2006;164:984-9.

20. Mahmud SM, Tanguayb S. Bégin LR, et al. Non-steroidal anti-inflammatory drug use and prostate cancer in a high-risk population. Eur I Cancer Prev 2006; 15:158-64.

21. Menezes RJ, Swede H, Mettlin C, et al. Regular aspirin use and risk of prostate cancer. Cancer Causes Control 2006; 17:251-6.

22. Nelson JE, Harris RE. Inverse association of prostate cancer and non-steroidal anti-inflammatory drugs (NSAIDs): results of a case-control study. Oncol Rep 2000;7:169-70.

23. Neugut Al, Rosenberg DJ, Ahsan H, et al. Association between coronary heart disease and cancers of the breast, prostate, and colon. Cancer Epidemiol Biomarkers Prev 1998;7:869-73.

24. Norrish AE, Jackson RT, McRae CU. Non-steroidal anti-inflammatory drugs and prostate cancer progression. Int J Cancer 1998;77:51 1-5.

25. Paganini-Hill A, Chao A, Ross RK, et al. Aspirin use and chronic diseases: a cohort study of the elderly. BMJ 1989;299:1247-50.

26. Perron L, Bairati I, Moore L, et al. Dosage, duration and timing of nonsteroidal anti-inflammatory drug use and risk of prostate cancer. Int J Cancer 2003;106:409-15

27. Roberts RO, Jacobson DJ, Girman CJ, et al. A population-based study of daily nonsteroidal anti-inflammatory drug use and prostate cancer. Mayo Clin Proc 2002;77:219-25.
28. Schreinemachers DM, Everson RB. Aspirin use and lung, colon, and breast cancer incidence in a prospective study. Epidemiology 1994;5:138-46.

29. Sørensen HT, Friis S, Nørgard B, et al. Risk of cancer in a large cohort of nonaspirin NSAID users: a population-based study. Br J Cancer 2003;88:1687-92.

30. Platz EA, Rohrmann S, Pearson JD, et al. Nonsteroidal anti-inflammatory drugs and risk of prostate cancer in the Baltimore Longitudinal Study of Aging. Cancer Epidemiol Biomarkers Prev 2005;14:390-6.

31. Narayanan BA, Narayanan NK, Pittman P, et al. Regression of mouse prostatic intraepithelial neoplasio by nonsteroidal anti inflammatory drugs is linked to the sequential effect on androgen receptor, vasculoendothelial growth factor, cyclooxygenases and AKT signaling in TRAMP model. Clin Cancer Res 2004:10:7727-37.

32. Palapattu G. S., Sutcliffe S., Bastian P. J., et al. Prostate carcinogenesis and inflammation: emerging insights. Carcinogenesis 2005;26:1170-81.

33. Gupta S, Ahmad N, Marengo SR, et al. Chemoprevention of prostate carcinogenesis by adifluoromethylornithine in TRAMP mice. Cancer Res 2000;60:5125-33.

34. Kirschenbaum A, Klausner AP, Lee R, et al. Expression of cyclooxygenase-1 and cyclooxygenase-2 in the human prostate. Urology 2000;56:671-6.

35. Madaan S, Abel PD, Chaudhary KS, et al. Cytoplasmic induction and over-expression of cyclooxygenase2 in human prostate cancer: implications for prevention and treatment. BJU Int 2000;86:736-41.

36. Tanii N, Kikugawa T, Yokoyama M. Immunohistochemical study of cyclooxygenases in prostatic adenocarcinoma; relationship to apoptosis and Bc-2 protein expression. Anticancer Res 2000;20:2313-9.

37. Narayanan BA, Condon MS, Bosland MC, et al. Suppression of N-methyl-N-nitrosourea (MNU)/ testosterone-induced rat prostate cancer growth by celecoxib: effects on $\mathrm{COX}-2$, cell cycle regulation and apoptosis mechanism(s). Clin Cancer Res 2003;9:3503-13.

38. Gupta S, Adhami VM, Subbarayan M, et al. Suppression of prostate carcinogenesis by dietary supplement of celecoxib in transgenic adenocarcinoma of the mouse prostate model. Cancer Res 2004;64:3334-43.

39. Patel MI, Subbaramaiah K, Du B, et al. Celecoxib inhibits prostate cancer growth: evidence of a cyclooxygenase- 2-independent mechanism. Clin Cancer Res 2005;11:1999-2007.

40. Stock DC, Groome PA, Siemens DR, et al. Effects of non-selective non-steroidal anti-inflammatory drugs on the aggressiveness of prostate cancer. Prostate 2008;68:1655-65.

41. Stock D, Groome PA, Siemens DR. Inflammation and prostate cancer: A future target for prevention and therapy? Urol Clin North Am 2008;35:117-30.

42. Pruthi RS, Derksen JE, Moore D, et al. Phase II trial of celecoxib in prostate-specific antigen recurrent prostate cancer after definitive radiation therapy or radical prostatectomy. Clin Cancer Res 2006; 12:2172-7.

43. Walter SD. Recall bias in epidemiologic studies. I Clin Epidemiol 1990;43:1431-2.

44. Sackett DL. Bias in analytical research. J Chronic Dis 1979;32:51-63.

45. Smith GD, Phillips AN. Confounding in epidemiological studies: why "independent" effects may not be all they seem. BMJ 1992;305:757-9.

Correspondence: Dr. Kourosh Afshar, Department of Urologic Sciences, University of British Columbia, Rm. K0-134, 4480 0ak St., Vancouver BC V6H 3V4; fax 604 875-2721; kafshar@cw.bc.ca

CUAJ is read by at least 3000 urologists and related specialists in Canada and around the world.

If you want to reach urologists, there is no better place for your classified advertisement. Please contact the journal at journal@cua.org or call 514 395-0376 x40 for a price list, specifications and deadlines. 